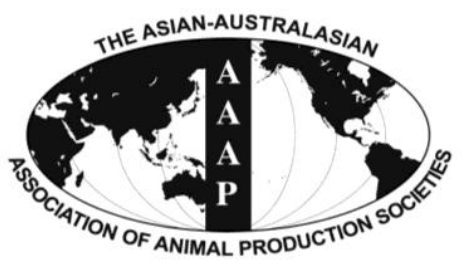

Asian-Aust. J. Anim. Sci.

Vol. 25, No. 6 : 839 - 844

June 2012

www.ajas.info

http://dx.doi.org/10.5713/ajas.2011.11468

\title{
Impacts of Limestone Multi-particle Size on Production Performance, Egg Shell Quality, and Egg Quality in Laying Hens
}

\author{
X. Y. Guo and I. H. Kim* \\ Department of Animal Resource and Science, Dankook University, \\ \#29 Anseodong, Cheonan, Choognam, 330-714, Korea
}

\begin{abstract}
This experiment was conducted to evaluate the effects of single or multi-particle size limestone on the egg shell quality, egg production, egg quality and feed intake in laying hens. A total of 280 laying hens (ISA brown) were used in this 10-wk trial. Laying hens were randomly assigned to 4 treatments with 14 replications per treatment and 5 adjacent cages as a replication (hens were caged individually). The experimental treatments were: i) L, basal diet+10\% large particle limestone; ii) LS1, basal diet+8\% large particle limestone $+2 \%$ small particle limestone; iii) LS2, basal diet+6\% large particle limestone+4\% small particle limestone; iv) S, basal diet $+10 \%$ small particle limestone. The egg production was unaffected by dietary treatments. The egg weight in $\mathrm{S}$ treatment was lighter than other treatments $(\mathrm{p}<0.05)$. The egg specific gravity in $\mathrm{S}$ treatment was lower than other treatments $(\mathrm{p}<0.05)$. The eggshell strength and eggshell thickness in S treatment were decreased when compared with other dietary treatments $(\mathrm{p}<0.05)$. The laying hens in LS1 and LS2 treatment had a higher average feed intake than the other two treatments $(\mathrm{p}<0.05)$. Collectively, the dietary multi-particle size limestone supplementation could be as efficient as large particle size limestone. (Key Words: Egg Quality, Egg Shell Quality, Layers, Limestone, Particle Size)
\end{abstract}

\section{INTRODUCTION}

A series of documented studies noted that calcium sources and particle sizes affect the egg shell quality and egg internal quality (Nys, 1999; Richter et al., 1999; Roland and Bryant, 2000; Boorman and Gunaratne, 2001). It is well accepted that each egg contains up to 3 grams of calcium (Roberts, 2004), and about 95\% of the dry eggshell is calcium carbonate (Pavlovski et al., 2003). Therefore, the diet of laying hens must contain adequate calcium in a form that can be utilized efficiently (Roberts, 2004). The main source of calcium in laying hen diets is pulverized limestone. A large amount of studies tried to investigate the effect of particle size on egg shell quality and egg internal quality, and determined the optimal particle size for laying hens (Guinotte, 1987; Cheng and Coon, 1990; Zhang and Coon, 1994; Ekmay and Coon, 2010). However, studies were emphasized the importance of determining an optimal single size limestone for laying hens, whereas limestone supplemented in diets in practice is not in a single particle size form, instead mainly in mix particle size form.

\footnotetext{
* Corresponding Author: I. H. Kim. Tel: +82-41-550-3652, Fax: +82-41-553-1618, E-mail: inhokim@dankook.ac.kr Submitted Dec. 7, 2011; Accepted Jan. 17, 2012; Revised Jan. 31, 2012
}

Moreover, younger hens have greater adaptive responses to calcium restriction than do older hens (Elaroussi et al., 1994), we still want to know the particle size of limestone whether have effects on laying hens newly starting to lay eggs (26 weeks of age). Therefore, our study was conducted to evaluate the effects of multi-particle size limestone supplementation on production performance, egg shell quality, and egg quality in laying hens.

\section{MATERIAL AND METHODS}

The protocol of management and experiment design was reviewed and approved by the Animal Care and Use Committee of Dankook University.

\section{Preparation of limestone}

The limestone was provided by Seoul Feed Co., Ltd. (Seoul, Korea) which had been finely ground to pass through No. 4 (large, sieve size $4.75 \mathrm{~mm}$ ) and 8 sieve (small, sieve size $2.38 \mathrm{~mm}$ ) (USA standard sieves), respectively.

\section{Birds and experiment design}

A total of 280 26-wk-old (ISA brown) laying hens were used in this 10-wk trial. Birds were randomly assigned to 1 
of 4 treatments with 14 replications per treatment and 5 adjacent cages as a replication (hens were caged individually). The experimental treatments were: i) L, basal diet $+10 \%$ large particle limestone; ii) LS1, basal diet $+8 \%$ large particle limestone $+2 \%$ small particle limestone; iii) LS2, basal diet+6\% large particle limestone+4\% small particle limestone; iv) $\mathrm{S}$, basal diet $+10 \%$ small particle limestone. Laying hens were raised in an ambient regulated house, in which temperature was maintained at $21^{\circ} \mathrm{C}$ and light regime was set at $16 \mathrm{~h}$ light: $8 \mathrm{~h}$ darkness. Laying hens were individually reared in adjacent steel cages which equipped with nipple drinker, trough and egg collecting plate. Birds were fed ad libitum accessed to water and feed.

\section{Samples and parameters}

Daily records of egg production and feed consumption were kept throughout the experimental period. Egg production was expressed as an average production of hen per day, which was calculated from the total number of eggs divided by the number of experimental time (day as a unit) and summarized on an average basis. The average daily feed intake was calculated during whole period of trial. A total of 42 salable eggs (no shell defects or cracks) were randomly collected biweekly from each treatment at 17:00 (3 eggs per replication). The egg quality of the collected eggs was then determined at 20:00 on the day of collection. Egg weight was measured using an egg multi tester (Touhoku Rhythm Co. Ltd., Tokyo, Japan). The total average egg weight was calculated based on biweekly egg weight measurement. Eggshell color was determined using a color fan. Eggshell breaking strength was evaluated using a model II egg shell force gauge (Robotmation Co., Ltd., Tokyo, Japan). A dial pipe gauge (Ozaki MFG Co., Ltd., Tokyo, Japan) was used to measure egg shell thickness,

Table 1. Diet composition (as-fed basis) ${ }^{1}$

\begin{tabular}{|c|c|c|c|c|}
\hline 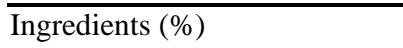 & $\mathrm{L}$ & LS1 & LS2 & $S$ \\
\hline$\overline{\text { Corn }}$ & 22.00 & 22.00 & 22.00 & 22.00 \\
\hline Soybean meal (CP 46\%) & 22.00 & 22.00 & 22.00 & 22.00 \\
\hline Wheat & 31.90 & 31.90 & 31.90 & 31.90 \\
\hline Grass meal & 2.00 & 2.00 & 2.00 & 2.00 \\
\hline Rapeseed cake & 4.00 & 4.00 & 4.00 & 4.00 \\
\hline Cornstarch & 6.00 & 6.00 & 6.00 & 6.00 \\
\hline Rapeseed oil & 2.50 & 2.50 & 2.50 & 2.50 \\
\hline Large particle size limestone & 10 & 8 & 6 & - \\
\hline Small particle size limestone & - & 2 & 4 & 10 \\
\hline Tricalcium phosphate (P 18\%) & 1.70 & 1.70 & 1.70 & 1.70 \\
\hline Salt & 0.30 & 0.30 & 0.30 & 0.30 \\
\hline DL-methionine $(50 \%)$ & 0.10 & 0.10 & 0.10 & 0.10 \\
\hline Vitamin-mineral premix ${ }^{2}$ & 0.50 & 0.50 & 0.50 & 0.50 \\
\hline \multicolumn{5}{|l|}{ Calculated composition (\%) } \\
\hline $\mathrm{ME}(\mathrm{kcal} / \mathrm{kg})$ & 2,739 & 2,739 & 2,739 & 2,739 \\
\hline $\mathrm{CP}$ & 16.80 & 16.80 & 16.80 & 16.80 \\
\hline Lys & 0.81 & 0.81 & 0.81 & 0.81 \\
\hline Met & 0.36 & 0.36 & 0.36 & 0.36 \\
\hline Met+cys & 0.66 & 0.66 & 0.66 & 0.66 \\
\hline $\mathrm{Ca}$ & 4.37 & 4.37 & 4.37 & 4.37 \\
\hline Total P & 0.61 & 0.61 & 0.61 & 0.61 \\
\hline Available P & 0.37 & 0.37 & 0.37 & 0.37 \\
\hline \multicolumn{5}{|l|}{ Analyzed composition (\%) } \\
\hline $\mathrm{ME}(\mathrm{kcal} / \mathrm{kg})$ & 2,725 & 2,728 & 2,725 & 2,727 \\
\hline $\mathrm{CP}$ & 16.78 & 16.78 & 16.79 & 16.78 \\
\hline Lys & 0.80 & 0.80 & 0.80 & 0.80 \\
\hline Met & 0.34 & 0.35 & 0.35 & 0.35 \\
\hline Met+cys & 0.63 & 0.64 & 0.65 & 0.64 \\
\hline $\mathrm{Ca}$ & 4.35 & 4.35 & 4.35 & 4.36 \\
\hline Total P & 0.61 & 0.60 & 0.60 & 0.60 \\
\hline Available P & 0.35 & 0.35 & 0.34 & 0.35 \\
\hline
\end{tabular}


Table 2. Egg production performance influenced by the dietary particle size ${ }^{1}$

\begin{tabular}{|c|c|c|c|c|c|c|c|c|c|c|}
\hline \multirow{2}{*}{ Parameter (wk) } & \multirow{2}{*}{ Trt } & \multirow{2}{*}{28} & \multirow{2}{*}{30} & \multirow{2}{*}{32} & \multirow{2}{*}{34} & \multirow{2}{*}{36} & \multirow{2}{*}{ SEM $^{2}$} & \multicolumn{3}{|c|}{ Main effects ${ }^{3}$} \\
\hline & & & & & & & & wk & Trt & $\mathrm{wk} \times \operatorname{Trt}$ \\
\hline \multirow[t]{4}{*}{ Egg production (\%) } & $\mathrm{L}$ & 97.0 & 97.4 & 97.8 & 98.1 & 98.4 & 0.51 & NS & NS & NS \\
\hline & LS1 & 96.9 & 97.5 & 97.7 & 98.1 & 98.2 & 0.54 & NS & NS & NS \\
\hline & LS2 & 96.9 & 97.3 & 97.9 & 98.5 & 98.4 & 0.59 & NS & NS & NS \\
\hline & S & 97.2 & 97.7 & 98.0 & 98.4 & 98.5 & 0.63 & NS & NS & NS \\
\hline
\end{tabular}

${ }^{1} \mathrm{~L}=$ Basal diet+10\% large particle limestone); LS1 = Basal diet $+8 \%$ large particle size limestone $+2 \%$ small particle size limestone; LS2 = Basal diet+large particle size limestone+4\% small particle size limestone; $\mathrm{S}=$ Basal diet $+10 \%$ small particle size limestone. Trt $=$ Treatment. $\mathrm{wk}=\mathrm{Week}$.

${ }^{2}$ Standard error of means. ${ }^{3} \mathrm{NS}=$ Non-significant. $\mathrm{p}<0.05$ means significant effect.

Table 3. Effect of dietary particle size of limestone on mean value of production performance ${ }^{1}$

\begin{tabular}{lccccc}
\hline Parameters & L & LS1 & LS2 & S & SEM $^{2}$ \\
\hline Egg production (\%) & 97.7 & 97.6 & 97.8 & 98.0 & 0.23 \\
Average daily feed intake $(\mathrm{g})$ & $137^{\mathrm{b}}$ & $140^{\mathrm{a}}$ & $140^{\mathrm{a}}$ & $137^{\mathrm{b}}$ & 0.60 \\
\hline
\end{tabular}

${ }^{1} \mathrm{~L}=$ Basal diet+10\% large particle limestone; LS1 = Basal diet+8\% large particle size limestone+2\% small particle size limestone; LS2 = Basal diet+large particle size limestone $+4 \%$ small particle size limestone; $\mathrm{S}=$ Basal diet $+10 \%$ small particle size limestone.

${ }^{2}$ Standard error of means. ${ }^{a, b}$ Means the same row with different superscripts differ $(\mathrm{p}<0.05)$.

which was determined based on the average thickness of the rounded end, pointed end, and the middle of the egg, excluding the inner membrane. Finally, egg weight, egg yolk color, and Haugh Unit (HU) were evaluated using an egg multi-tester (Touhoku Rhythm Co. Lt., Tokyo, Japan). Egg specific gravity was conducted using 42 eggs randomly from each replication on a biweekly basis. These eggs were immersed in a series of sodium chloride solution (0.010increments between 1.060 and 1.110) to determine specific gravity.

\section{Statistic analysis}

All data were arranged to evaluate by analysis of variance following the GLM procedure in a completely randomized design using the SAS software program (SAS Institute, 1996). Laying hens were blocked with identical age. The statistical model included the main and interactive effects of age (weeks) and treatment. The difference among treatment was compared using the Duncan's multiple range test. The treatment effect was observed significant with the probability value below 0.05 .

\section{RESULTS}

\section{Production performance}

No difference was found in growth production among treatments (Tables 2 and 3). The laying hens in LS1 and LS2 treatment have higher average feed intake than the other two treatments $(\mathrm{p}<0.05)$.

\section{Egg shell quality}

The egg weight in $\mathrm{S}$ treatment was lighter than the other treatments $(\mathrm{p}<0.05)$. The egg specific gravity in $\mathrm{S}$ treatment was lower than the other treatments $(\mathrm{p}<0.05)$ (Table 4$)$. The eggshell strength and eggshell thickness in S treatment were decreased compared with other dietary treatments $(\mathrm{p}<0.05)$. The egg shell color was unaffected by the dietary treatments.

\section{Egg quality}

There was no difference in egg yolk height and Haugh unit among treatments (Table 5). The egg yolk color in $\mathrm{S}$ treatment was lighter than other treatments $(\mathrm{p}<0.05)$.

\section{DISCUSSION}

The reports about the addition of particulate limestone to the diet have documented inconsistent results in laying hens. Dietary supplementation of 50\% oyster shell along with limestone has increased egg production in broiler breeders and caged laying hens (Van Wambeke and DeGroote, 1986; Ahmad and Balander, 2003). However, Guinote (1987) pointed that only 13 of 51 studies have showed a positive effect on egg production with particle calcium. Ekmay and Coon (2010) also demonstrated that particle size did not positively affect the egg production in 3 different purelines of laying hens. In the present study, the egg production was unaffected by the limestone particle sizes. Jonets (2007) has previously suggested that calcium level in diets and genetic line could affect egg production. In this study, the calcium levels of diets were kept identical among treatments, and hens were from the same genetic line. Thus, our results suggested that particle size will not affect the egg production. The age of laying hens has not affected the egg production. It may be attributed to most strains of laying hens become sexually mature at 22 to 24 wks and lay well for 12 to 14 months (Stadelman and Cotterill, 1977).

Previously, Ekmay and Coon (2009) suggested that 
Table 4. Eggshell profiles influenced by the dietary limestone particle size $\mathrm{e}^{1,2}$

\begin{tabular}{|c|c|c|c|c|c|c|}
\hline $\begin{array}{l}\text { Parameter } \\
\text { (wk) }\end{array}$ & Trt & Eggshell color & $\begin{array}{l}\text { Egg weight } \\
\text { (g) }\end{array}$ & Egg gravity & $\begin{array}{l}\text { Eggshell strength } \\
\left(\mathrm{kg} / \mathrm{cm}^{2}\right)\end{array}$ & $\begin{array}{c}\text { Eggshell thickness } \\
(0.01 \mathrm{~mm})\end{array}$ \\
\hline \multirow[t]{4}{*}{28} & $\mathrm{~L}$ & 11.4 & 61.5 & 1.090 & 3.876 & 37 \\
\hline & LS1 & 11.8 & 61.6 & 1.090 & 3.838 & 37 \\
\hline & LS2 & 11.0 & 61.6 & 1.090 & 3.830 & 37 \\
\hline & S & 11.1 & 61.5 & 1.080 & 3.401 & 36 \\
\hline \multirow[t]{4}{*}{30} & $\mathrm{~L}$ & 11.4 & 61.6 & 1.100 & 3.904 & 38 \\
\hline & LS1 & 12.4 & 61.7 & 1.100 & 3.843 & 38 \\
\hline & LS2 & 11.3 & 61.7 & 1.110 & 3.836 & 38 \\
\hline & S & 10.7 & 61.5 & 1.090 & 3.411 & 38 \\
\hline \multirow[t]{4}{*}{32} & $\mathrm{~L}$ & 11.5 & 62.0 & 1.100 & 3.912 & 39 \\
\hline & LS1 & 11.9 & 62.0 & 1.100 & 3.865 & 38 \\
\hline & LS2 & 11.3 & 62.0 & 1.100 & 3.846 & 39 \\
\hline & $S$ & 10.9 & 61.6 & 1.090 & 3.435 & 37 \\
\hline \multirow[t]{4}{*}{34} & $\mathrm{~L}$ & 11.3 & 62.0 & 1.100 & 3.940 & 40 \\
\hline & LS1 & 12.2 & 62.2 & 1.100 & 3.870 & 41 \\
\hline & LS2 & 10.8 & 62.2 & 1.100 & 3.857 & 40 \\
\hline & S & 11.2 & 61.8 & 1.100 & 3.459 & 39 \\
\hline \multirow[t]{4}{*}{36} & $\mathrm{~L}$ & 11.3 & 62.1 & 1.110 & 3.948 & 41 \\
\hline & LS1 & 11.7 & 62.4 & 1.110 & 3.884 & 41 \\
\hline & LS2 & 11.0 & 62.4 & 1.110 & 3.865 & 42 \\
\hline & $S$ & 11.1 & 62.1 & 1.090 & 3.466 & 40 \\
\hline \multirow[t]{4}{*}{ Overall period ${ }^{3}$} & $\mathrm{~L}$ & 11.4 & $61.8^{\mathrm{a}}$ & $1.100^{\mathrm{a}}$ & $3.916^{\mathrm{a}}$ & $39^{\mathrm{a}}$ \\
\hline & LS1 & 12.0 & $61.9^{\mathrm{a}}$ & $1.100^{\mathrm{a}}$ & $3.860^{\mathrm{a}}$ & $39^{\mathrm{a}}$ \\
\hline & LS2 & 11.1 & $62.0^{\mathrm{a}}$ & $1.100^{\mathrm{a}}$ & $3.847^{\mathrm{a}}$ & $39^{\mathrm{a}}$ \\
\hline & S & 11.0 & $61.7^{\mathrm{b}}$ & $1.090^{\mathrm{b}}$ & $3.434^{\mathrm{b}}$ & $38^{\mathrm{b}}$ \\
\hline $\mathrm{SEM}^{4}$ & & 0.33 & 0.06 & 0.003 & 0.060 & 0.27 \\
\hline \multicolumn{2}{|l|}{ Main effects ${ }^{4}$} & - & - & - p-value & --- & - \\
\hline wk & & NS & 0.02 & NS & NS & NS \\
\hline Trt & & NS & 0.04 & 0.04 & 0.03 & 0.01 \\
\hline$w k \times \operatorname{Trt}$ & & NS & 0.03 & NS & NS & NS \\
\hline
\end{tabular}

${ }^{1} \mathrm{~L}=$ Basal diet+10\% large particle limestone); LS1 = Basal diet+8\% large particle size limestone+2\% small particle size limestone; LS2 = Basal diet+large particle size limestone $+4 \%$ small particle size limestone; $\mathrm{S}=$ Basal diet+10\% small particle size limestone). Trt $=$ Treatment. $w \mathrm{k}=\mathrm{Week}$.

${ }^{2}$ Means represent values derived from 42 eggs per treatment. ${ }^{3}$ The mean value of overall period data (26 to $\left.36 \mathrm{wk}\right)$.

${ }^{4}$ Standard error of means. ${ }^{5} \mathrm{NS}=$ Non-significant. $\mathrm{p}<0.05$ means significant effect.

large particle limestone in the diets of Cobb 500 breeders through 40 wks of age significantly improved egg weight compared with those fed small particle limestone. Similarly, our result demonstrated that large particle size limestone increased the egg weight. However, Pavlovski et al. (2003) noted that fine pulverized limestone partially replaced by granular limestone did not affected the egg mass. Although studies showed that the egg weight can be influenced by particle size, but it appears that the genetic line also affects the egg weight (Ekmay and Coon, 2010). Thus, genetic lines need to be taken into consideration when evaluating the effect of limestone particle size on egg weight.

Egg specific gravity is an indirect indicator of the amount of shell present in relation to the size of the egg
(Roberts, 2004). Pavlovski et al. (2003) found that replacing fine pulverized limestone with granular limestone in diet at $80 \%$ increased the egg shell mass. Ekmay and Coon (2009) had previously suggested that the specific gravity was improved by dietary supplementation large particle limestone. Manangi and Coon (2006) also revealed that including large particle limestone in the diet of 32-wk old Cobb 500 broiler breeders improved specific gravity over a period of $6 \mathrm{wk}$. In agreement with these reports, the present study also demonstrated that diets contain large particle limestone increased specific gravity.

A large amount of studies have reported that egg shell thickness and egg shell strength could be improved by using limestone of large particle size as a calcium source in diets 
Table 5. Egg quality influenced by the limestone particle size ${ }^{1,2}$

\begin{tabular}{|c|c|c|c|c|}
\hline $\begin{array}{l}\text { Parameter } \\
\text { (wk) }\end{array}$ & Trt & $\begin{array}{l}\text { Yolk } \\
\text { color }\end{array}$ & $\begin{array}{l}\text { Yolk height } \\
\quad(\mathrm{mm})\end{array}$ & $\begin{array}{c}\text { Haugh } \\
\text { unit }\end{array}$ \\
\hline \multirow[t]{4}{*}{28} & $\mathrm{~L}$ & 8.0 & 7.9 & 88.2 \\
\hline & LS1 & 7.8 & 8.1 & 88.9 \\
\hline & $\mathrm{LS} 2$ & 8.0 & 8.1 & 89.7 \\
\hline & S & 7.3 & 8.2 & 89.1 \\
\hline \multirow[t]{4}{*}{30} & $\mathrm{~L}$ & 8.2 & 8.1 & 88.4 \\
\hline & LS1 & 7.8 & 8.3 & 90.8 \\
\hline & LS2 & 7.9 & 8.3 & 89.5 \\
\hline & $S$ & 7.4 & 8.4 & 89.6 \\
\hline \multirow[t]{4}{*}{32} & $\mathrm{~L}$ & 8.1 & 8.2 & 89.0 \\
\hline & LS1 & 8.0 & 8.2 & 89.6 \\
\hline & $\mathrm{LS} 2$ & 8.1 & 8.1 & 88.9 \\
\hline & S & 7.6 & 8.5 & 89.5 \\
\hline \multirow[t]{4}{*}{34} & $\mathrm{~L}$ & 8.2 & 8.3 & 89.5 \\
\hline & LS1 & 7.9 & 8.4 & 90.8 \\
\hline & $\mathrm{LS} 2$ & 8.2 & 8.2 & 89.4 \\
\hline & $\mathrm{S}$ & 7.5 & 8.4 & 90.2 \\
\hline \multirow[t]{4}{*}{36} & $\mathrm{~L}$ & 8.2 & 8.2 & 89.4 \\
\hline & LS1 & 8.1 & 8.5 & 90.5 \\
\hline & $\mathrm{LS} 2$ & 7.9 & 8.1 & 89.6 \\
\hline & S & 7.5 & 8.4 & 90.1 \\
\hline \multirow[t]{4}{*}{ Overall period ${ }^{3}$} & $\mathrm{~L}$ & $8.1^{\mathrm{a}}$ & 8.1 & 88.9 \\
\hline & LS1 & $7.9^{\mathrm{a}}$ & 8.3 & 90.1 \\
\hline & LS2 & $8.0^{\mathrm{a}}$ & 8.2 & 89.4 \\
\hline & $\mathrm{S}$ & $7.5^{\mathrm{b}}$ & 8.3 & 89.7 \\
\hline $\mathrm{SEM}^{4}$ & & 0.13 & 0.09 & 0.55 \\
\hline \multicolumn{2}{|l|}{ Main effects ${ }^{5}$} & -1 & p-value - & ---- \\
\hline wk & & NS & NS & NS \\
\hline Trt & & 0.03 & NS & NS \\
\hline$w k \times \operatorname{Trt}$ & & NS & NS & NS \\
\hline
\end{tabular}

${ }^{1} \mathrm{~L}=$ Basal diet $+10 \%$ large particle limestone; $\mathrm{LS1}=$ Basal diet+ $8 \%$ large particle size limestone $+2 \%$ small particle size limestone; LS2 $=$ Basal diet+large particle size limestone+4\% small particle size limestone; $\mathrm{S}=$ Basal diet $+10 \%$ small particle size limestone. Trt $=$ Treatment; $\mathrm{wk}=$ Week.

${ }^{2}$ Means represent values derived from 42 eggs per treatment.

${ }^{3}$ The mean value of overall period data (26 to $36 \mathrm{wk}$ ).

${ }^{4}$ Standard error of means.

${ }^{5} \mathrm{NS}=$ Non-significant. $\mathrm{p}<0.05$ means significant effect.

for hens (Guinote and Nus, 1991; Roberts and Nolan, 1997; Pavlovski et al., 2000; Pavlovski et al., 2003). Roland and Bryant (1999) suggested that replacing 50\% of ground limestone by large particle size limestone is quite adequate to optimize eggshell quality. In the present trial, the egg shell thickness and egg strength were also increased when laying hens fed with large particle size limestone and mix particle size limestone. These results indicated that layers fed mix particle size limestone as efficient as the large particle limestone on the eggshell quality. Furthermore, the amount and thickness of egg shell have been found to be related to egg shell strength. The strength of an egg is determined not just by the amount of shell that is present, but also by the quality of construction of the shell (Roberts, 2004). Therefore, further studies are still necessary to investigate if the improvement of eggshell quality was caused by the increment of eggshell mass, or by the changing of ultra-construction of eggshell, or by both of them.

The calcium solubility of calcium carbonate is unaffected by particle size (Ajakaiye, 1996). However, several studies suggested that larger particle size limestone led to an increment in gizzard and duodenal soluble calcium at the end of eggshell calcification in laying hens (Kermanchoi et al., 1991; Zhang and Coon, 1994; Guinote et al., 1995). Zhang and Coon (1994) had confirmed that large particle limestone is retained for a longer period of time in the gizzard of commercial laying hens, and the slowly dissolve process of large particle limestone may be advantageous to accommodate needs for eggshell formation (Ajakaiye et al., 1997), therefore, we hypothesized that the reason for the increased egg shell mass, egg thickness and egg strength may be explained by the slowly but continuously dissolve process of large particle limestone, which make sure calcium can be steadily absorbed in digest tract of laying hens.

The egg quality (egg yolk height and Haugh unit) was unaffected by dietary treatments. However, the egg yolk color was decreased in S treatment. It is well accepted that the egg yolk color is correlated with pigment content. However, limited researches showed that calcium involves the coloration of egg yolk. Limestone has usually been used as a kind of calcium source. Calcium content correlated with yellow pigment, and yellow pigment of egg shell decreased as calcium increased (Jones, 2007). Yang et al. (2009) suggested that egg shell color was correlated with egg yolk color. The calcium content of shell reduced when the shell color became more and more shallow, however, the egg yolk color slightly decreased, although no significant difference was observed. Tortuero and Centeno (1977) found that increasing the dietary level of calcium from 3.0 to $4.0 \%$ reduced egg yolk color by almost one unit on the Roche color fan. Considering the inconsistent results, we need to confirm the relationship between calcium content and egg yolk color.

The feed intake in $\mathrm{L}$ and $\mathrm{S}$ treatment were lower than LS1 and LS2 treatment. We infer that large particle size of limestone will retain for a long period in digestive tract, which improved the energy digestibility (Nam et al., 1999) and inhibited the feed intake (Richard, 2003). If the particle size of limestone too small, the limestone will be excreted fast, and weakly rub the feed by gizzard, this may also affect the feed intake.

Collectively, the mixture of two particle sizes limestone 
could be as efficient as the large particle size limestone. The large particle size limestone and mix particle size limestone are more beneficial to layers than small particle size limestone. The inclusion of limestone in diets is beneficial to improve egg shell quality of laying hens newly starting to lay eggs.

\section{REFERENCES}

Ahmad, H. A. and R. J. Balander. 2003. Alternative feeding regimen of calcium source and phosphorus level for better eggshell quality in commercial layers. J. Appl. Poult. Res. 12: 509-154.

Ajakaiye, A., J. O. Atteh and S. Leeson. 1996. Effects of calcium source, particle size and time on in-vitro calcium solubility of some indigenous Nigerian mineral ingredients for poultry diets. Anim. Feed Sci. Technol. 65:293-298.

Boorman, K. N. and S. P. Gunaratne. 2001. Dietary phosphorus supply, egg-shell deposition and plasma inorganic phosphorus in laying hens. Br. Poult. Sci. 42:81-91.

Cheng, T. K. and C. N. Coon. 1990. Effect on layer performance and shell quality of switching limestone with different solubilities. Poult. Sci. 69:2199-2203.

Ekmay, R. D. and C. N. Coon. 2009. The effects of reduced NPP levels and limestone particle size on production, skeletal integrity, progeny quality and $\mathrm{P}$ balance in broiler breeder hens. Short communications. Page 189 In: Proceedings and abstracts of 17th European Symposium on Poultry Nutrition, Edinburgh, Scotland.

Ekmay, R. D. and C. N. Coon. 2010. The effect of limestone particle size on the performance of three broiler breeder purelines. Int. J. Poult. Sci. 9(11):8-1042.

Elaroussi, M. A., L. R. Forte, S. L. Eber and H. V. Biellier. 1994. Calcium homeostasis in the laying hen. Poult. Sci. 73:15811589.

Guinote, F. 1987. Efficacité de différentes sources de calcium pour l'ossification du poulet et la qualité de la coquille de l'oeuf. Rôle de la sécrétion acide dans leur utilization digestive. Rapport Bibliographique, Station de Recherches Avicoles, INRA Tours-Nouzilly, pp. 1-56.

Guinote, F. and Y. Nys. 1991. Effects of particle size and origin of calcium sources on eggshell quality and bone mineralization in egg of laying hens. Poult. Sci. 70:583-92.

Guinote, F., J. Gautron, Y. Nys and A. Soumarmon. 1995. Calcium solublization and retention in the gastro-intestinal tract in chicks (Gallus domesticus) as a function of gastric acid secretion inhibition and of calcium carbonate particle size. $\mathrm{Br}$. J. Nutr. 73(1):125-39.

Jones, L. R. 2007. Calcium dynamics affecting egg production, skeletal integrity, and egg coloration in ring-necked pheasants (Phasianus colchicus). Master Diss. Brigham Young Univ., Provo, Utah.
Kermanchoi, H. and A. Golion. 1991. Effects of various sources of calcium upon egg shell quality and laying hen performance. Quality of Poultry Products. II Eggs and egg products, 147-59.

Manangi, M. and C. N. Coon. 2006. Calcium particle size effects on plasma, excreta and urinary $\mathrm{Ca}$ and $\mathrm{P}$ changes in broiler breeder hens. Poult. Sci. 85(Suppl.1):30.

Nam, K. T., H. A. Lee, Y. J. Joo, K. H. Kim and C. W. Kang. 1998. Influence of builder's sand on the TME of linseed for poultry. Anim. Feed Sci. Technol. 72:199-201.

Nys, Y. 1999. Nutritional factors affecting eggshell quality. Czech J. Anim. Sci. 44:135-143.

Pavlovski, Z., D. Vitorović, Z. Škrbić and S. Vraćar. 2000. Influence of limestone particle size in diets for hens and oviposition time on eggshell quality. Acta Vet. 50:37-42.

Pavlovski Z., D. Vitorović, M. Lukić and Spasojević Ivana. 2003. Improving eggshell quality by replacement of puverised limestone by granular limestone in the hen diet. Acta Vet. (Beograd) 53:35-40.

Richard, M. P. 2003. Genetic regulation of feed intake and energy balance in poultry. Poult. Sci. 82:907-916.

Richter, G., G. Kiessling, W. I. Ochrimenko and H. Ludke. 1999. Influence of particle size and calcium source on limestone solubility in vitro, performance and eggshell quality in laying hens. Arch. Geflugelkunde 63:208-213.

Roberts, J. and J. Nolan. 1997. Egg and egg shell quality in five strains of laying hen and the effect of calcium source and hen age. Proc. The 13th and 7th European Symposium on the quality of poultry meat and on the quality of eggs and egg products.Poznan, Poland, Sept. 21-26.

Roberts, J. R. 2004. Factors affecting egg internal quality and egg shell quality in laying hens. J. Poult. Sci. 41:161-177.

Roland, D. and M. Bryant. 1999. Optimal shell quality is possible without oyster shell. Feedstuffs 18-19.

Roland, D. A. and M. Bryant. 2000. Nutrition and feeding for optimum egg shell quality. Proc. The XXI world's Poultry Congress, Montreal, Canada.

Stadelman, W. J. and O. J. Coterill. 1977. Egg production practice. In: Egg science and technology, 2nd Ed. AVI publishing company, ING, Westport, Connecticut. p. 23.

Tortuero, F. and C. Centeno. 1977. Influence of different dietary calcium levels on carotenoid utilization in egg yolk pigmentation. Avances en alimentacion y mejora animal. 18:501-504.

Van Wambeke, F. and G. DeGroote. 1986. L'influence du moment de l'alimentation et du replacement partiel de la craie en poudre par des coquilles d'huitres comme source de calcium sur les resultats de reproduction de deux souches de poules reproduction du type chair. Rev. I'Agric. 39:137.

Yang, M. H., Z. Y. Wang and J. Lu. 2009. Study on the relationship between egg colors and egg quality as well as shell ultrastructure in Yangzhou chicken. Afr. J. Biotechnol. 8:28982902.

Zhang, B. and C. Coon. 1997. The relationship of calcium intake, source, size solubility in vitro and in vivo and gizzard limestone retention in laying hens. Poult. Sci. 76:1702-1706. 